くなりかつ見掛けの重合活性化エネルギーが低下しているが，そ れは次のよ5な電子効果*3 亿起因すると考えられる。

電子供与性置換基の効果により，スズ原子の電子密度が增加 し, $\mathrm{OR}^{\prime}$ の酸素原子の電子密度が増し， $\ominus \mathrm{OR}^{\prime}$ がより $\mathrm{EO} の \mathrm{C}^{\delta^{+}}$ を攻撃しやすくなるためと考兄られ，一方電子吸引性置換基の効 果によりスズ原子密度が低下し，スズ原子に配位した EO の炭素 原子の電子密度が低下し， $\ominus \mathrm{OR}^{\prime}$ の攻撃を受けやすくなるためと 考觉られる(図 11)。

ところで $\left(p-\mathrm{ClC}_{6} \mathrm{H}_{4} \mathrm{SnOOH}\right)_{n}$ 触媒系の場合には他の触媒系に 比して多量のジオキサンの副生が認められたが，これは電子吸引 性置換基効果により，スズ原子に配位した EO の炭素原子がより カチオン性（電子密度が低下したため）になったため，周囲に介 在する $\mathrm{EO}$ の酸素原子が，カチオン性炭素原子を攻撃して開環 し，生長末端カチオンを生成するカチオン重合機構をよりとりや

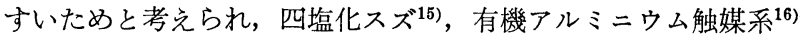
に類似した機構が考吕らる。

$\left(o-\mathrm{CH}_{3} \mathrm{C}_{6} \mathrm{H}_{4} \mathrm{SnOOH}\right)_{n}$ 触媒の重合速度定数は, 同程度の見掛け の重合活性化エネルギーを持つ $\left(p-\mathrm{CH}_{3} \mathrm{C}_{6} \mathrm{H}_{4} \mathrm{SnOOH}\right)_{n}$ 触媒に比 較して小さいのは, $\mathrm{CH}_{3}$ 基がオルト位にあるため立体障害とな り，EO のスズ原子への配位を妨げ，触媒活性点が減少している （触媒効率が小さい）ためと考えられる。

置換アリール亜スズ酸を加熱処理して得られた化合物を触媒と してEOの重合を行なったところ，重合体収率就よび重合体の分 子量の増加が認められたが，本実験の範囲内では，熱処理効果の 原因については不明であり，現在さらに詳細に検討を加えてい る。

終りに，本実験に協力された小波津隆市氏に感謝致します。

\title{
$\beta$-クロルプロピオンアルデヒドの重合および $\beta$-シアノプロピオンアルデヒドとの共重合
}

(昭 和 45 年 5 月 21 日 受 理)

\author{
住友 宏 ${ }^{* 1}$. 東 貴四 郎 ${ }^{* 2}$
}

\begin{abstract}
ß-クロルプロピオンアルデヒド (CIPA) を有機フルミニウム化合物を開始剤として低温で重合させて，ポリクロルェチルオキシ メチレンを得た。重合速度は塩化メチレン中ですっとも大きく，トルェンフテトラヒドロフランの順に低下した。ポリマー収量は $-90^{\circ} \mathrm{C}$ 付近で最大で, $-45^{\circ} \mathrm{C}$ 以上の温度では高重合体はほとんど得られなかった。 $\mathrm{AlEt}_{3}, \mathrm{AlEt}_{2} \mathrm{Cl}, \mathrm{AlEtCl}_{2}, \mathrm{AlCl}_{3}$ およびそれ らの組合せにつき，開始剤の酸強度の影響をしらべた。 $\mathrm{AlEt}_{3}$ と $\mathrm{TiCl}_{4}$ または $\mathrm{TiCl}_{3}$ との複合開始剤に怙ける $\mathrm{Ti} / \mathrm{Al}$ 比のポリマ 一収量拉よびポリマー構造におよぼす効果も検討した。ClPA と $\beta$-シアノプロピオンアルデヒドとの共重合を $\mathrm{AlEt}_{3}$ を開始剤と して行ない，生成物が共重合体であることを確認した。共重合させることによって両ホモポリマ一のいずれよりる溶解性に富む共 重合体を得ることができる。共重合体組成はつねとモノマ一仕込組成にほぼ一致し，ランダムなアゼオトロ一プ共重合である。ま た共モノマーを少量添加した組成に拈ける共重合が，飽和ポリマー収量または重合速度の最大值を与えるという興味ある現象をみ いだした。
\end{abstract}

\section{1 緒 言}

塩素化アルデヒドの線状高重合についてはクロラール1)をはじ めとする塩素化アセトアルデヒド2) の重合がしられている。著者 らの研究室では極性置換基を有するポリオキシメチレンの合成に

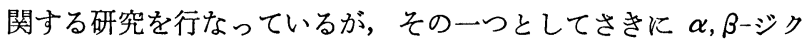
ロルプロピオンアルデヒド (DCPA) の重合を報告した ${ }^{3)}$ 。今回は DCPA と同じくアクロレインからつくられる $\beta$ ークロルプロピオ ンアルデヒド (CIPA) を重合させることにより，新たにポリ $\beta$ クロルエチルオキシメチレンを得た。CIPA の合成は古く 1859 年になされているがその重合については環状三量体を与えるとい う程度しかしられていない4。本報では主として有機アルミニウ

*1 Hiroshi SUMITOMO 名古屋大学農学部 : 名古屋市千種区 不老町.

*2 Kishiro AZUMA 東亜合成化学工業（株）研究所：名古屋 市港区船見町.

1) A. Novak, E. Whalley, Trans. Faraday Soc., 55, 1490 (1959).

2) 例えば T. Iwata, G. Wasai, T. Saegusa, J. Furukawa, Makromol. Chem., 77, 229 (1964).

3) H.Sumitomo, T. Nakagawa, J.Polym.Sci., Part B, 7 , 739 (1969).

4) E.H.Huntress, "Organic Chlorine Compounds", John Wiley, N. Y. (1948), p. 725 ,
ム化合物を開始剤とする CIPA の重合および $\beta$-シアノプロピオ ンアルデヒド $(\mathrm{CPA})$ との共重合を行なった結果について述べ る。

\section{2 実験}

\section{$2 \cdot 1$ 試 薬}

及-クロルプロピオンアルデヒド (ClPA)：アクロレイン中に -15 $0^{\circ} \mathrm{C}$ に打いて乾燥塩化水素を通じて理論量の $90 \mathrm{~mol} \%$ を 吸収反応させたのち減圧下で精留し, bp $45.5 \sim 46.0^{\circ} \mathrm{C} / 26 \mathrm{mmHg}$ の留分 (収率 $47 \%$ ) をとって重合に用いた。

ß-シアノプロピオンアルデヒド (CPA)：その調製，精製执よ び重合については既報5,6)のと拈りである。

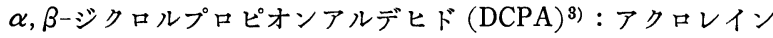
の四塩化炭素溶液中に乾燥塩素を $0^{\circ} \mathrm{C}$ に扣いて理論量の 1.4 倍モ ル量通じたのち減圧下で精留し, bp $62^{\circ} \mathrm{C} / 31 \mathrm{mmHg}$ の留分をと って重合に用いた。

開始剂：トリエチルアルミニウム $\left(\mathrm{AlEt}_{3}\right)$, ジェチルアルミニ ウムクロリド $\left(\mathrm{AlEt}_{2} \mathrm{Cl}\right)$ およびェチルアルミニウムジクロリド

5) H. Sumitomo, K. Kobayashi, J.Polym.Sci., Part A-1, 4, 907 (1966).

6) H. Sumitomo, K. Kobayashi, J.Polym.Sci., Part A-1, 5, 2247 (1967). 
$\left(\mathrm{AlEtCl}_{2}\right)$ は Ethyl Corp. 製品を，三塩化チタン $\left(\mathrm{TiCl}_{3}, \alpha\right.$ 型 $)$ は市販品をそのまま用いた。四塩化チタンン $\left(\mathrm{TiCl}_{4}\right)$ は $1 \%$ 銅粉 とともに 4 時間還流してから蒸留した。塩化アルミニウム $\left(\mathrm{AlCl}_{3}\right)$ は減圧昇華させて精製した。三フッ化ホウ素エーテレート $\left(\mathrm{BF}_{3}\right.$. $\mathrm{OEt}_{2}$ ）は窒素気流中で蒸留して用いた。

溶媒：塩化メチレン，トルエソ拉よびテトラヒドロフラン (THF) はいずれも常法により精製した。

\section{$2 \cdot 2$ 重 合 ${ }^{5 \sim 7)}$}

重合用試験管に所定量の開始剤溶液をいれ，液体窒素で涷結さ せ，これに冷却したモノマー溶液を加えたのちらたたび涷結させ る。この仕込操作は窒素置換された乾燥箱内で行なら。脱気溶封 後所定温度に静置し重合させた。最初均一であった反応系は, 重 合開始とともに不透明なゲル状に变る。一定時間後内容物を冷メ タノールまたは塩酸酸性冷メタノール中に投入してポリマーを沈 殿させ, 口過, 減圧乾燥した。

\section{$2 \cdot 3$ ジメチルホルムアミド（DMF）による溶出分別}

試料ポリマー $1 \mathrm{~g}$ に対して DMF 20〜50 $\mathrm{ml}$ を加兄, 室温で かきまぜたのち遠心分離する操作を，上澄液にメタノールを加え ても白濁を生じなくなるまでくり返したのち口過し,メタノール で洗って減圧乾燥して DMF 不溶分を，また上澄液を集めて減圧 濃縮したものからメタノールで沈殿させて DMF 可溶分を得る。

\section{3 結果および考察}

\section{$3 \cdot 1$ CIPA の 重 合}

$\mathrm{AlEt}_{3}$ を開始剤として塩化メチレン中 $-78^{\circ} \mathrm{C}$ に抢いて ClPA を重合させて白色粉末として得られるポリマーの IR スペクトル を図 1 に示す。モノマーのスペクトルにみられた波数 $1725 \mathrm{~cm}^{-1}$ のカルボニル基吸収が消失し，新たにェーテル結合による吸収が $900 \sim 1200 \mathrm{~cm}^{-1}$ の領域にあらわれており, $730 \mathrm{~cm}^{-1}$ には C-Cl にもとづく吸収があり，この生成物がポリ $\beta$-クロルエチルオキ シメチレン構造を有することを支持する。表 1 にこのポリマーの 元素分析結果を揭げた。

$$
n \mathrm{ClCH}_{2} \mathrm{CH}_{2} \mathrm{CHO} \longrightarrow \underset{\mathrm{CH}_{2} \mathrm{CH}_{2} \mathrm{Cl}}{+\mathrm{CH}-\mathrm{O}-)_{n}}
$$

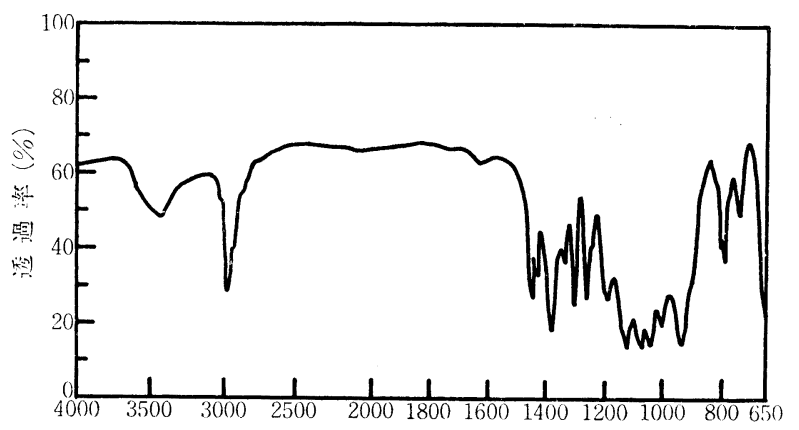

$$
\text { 波 数 }\left(\mathrm{cm}^{-1}\right)
$$

図 1 ポリクロルエチルオキシメチレンの赤外吸収 スペクトル $(\mathrm{KBr}$ 法 $)$

表 1 生成ポリマーの元素分析結果

\begin{tabular}{llll} 
& $\begin{array}{c}\mathrm{C} \\
(\%)\end{array}$ & $\begin{array}{c}\mathrm{H} \\
(\%)\end{array}$ & $\begin{array}{c}\mathrm{Cl} \\
(\%)\end{array}$ \\
\hline 実貺値 & 39.26 & 5.54 & 37.71 \\
計算值 $\left(\mathrm{C}_{3} \mathrm{H}_{5} \mathrm{OCl}\right)$ & 38.94 & 5.45 & 38.32
\end{tabular}

7) K. Kobayashi, H.Sumitomo, J.Polym.Sci., Part A-1, 7, 925 (1969).

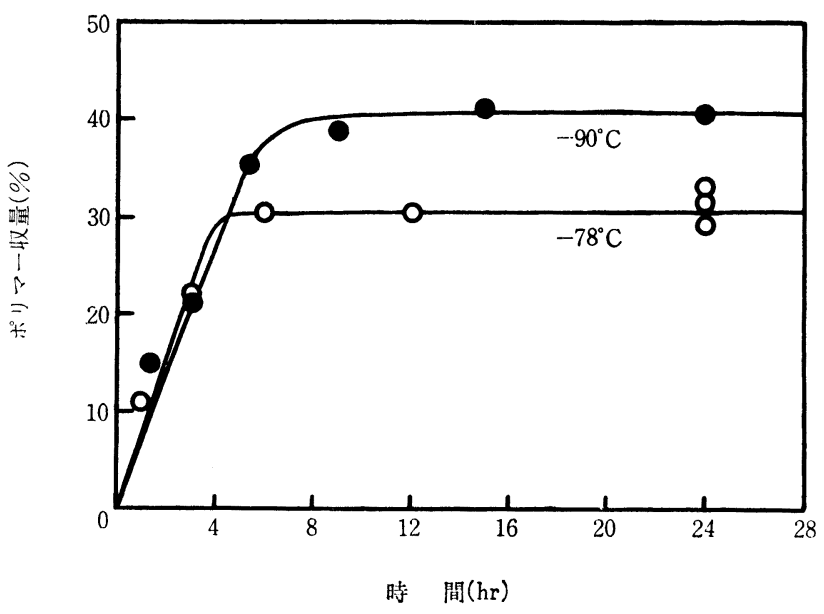

図 $2 \mathrm{AlEt}_{3}$ による $\mathrm{ClPA}$ の重合

$\mathrm{AlEt}_{3} 2 \mathrm{~mol} \% / モ ノ マ ー$ 塩化メチレン $2:$ モノマー $1(\mathrm{wt})$

このポリマーの各種溶剤に対 表 2 ClPA の重合におよぽす する溶解性は低く，これを溶か 寸溶媒はみつかっていない。X 線回折スペクトルにより結晶性 をしらべたところ， $2 \theta=10^{\circ} に$ 結晶性にもとづくと思われるピ 一クがみられるが, $2 \theta=18 \sim$ $23^{\circ}$ には非晶性にもとづくブロ ードなハローがあり，結晶性は あまり高くはない。

表 2 は $\mathrm{AlEt}_{3}$ を開始剤とする CIPA の重合に扮ける溶媒の影 響をしらべた結果で，ポリマー 収量は塩化メチレン>トルェン $>\mathrm{THF}$ の順に低下することが わかる。表 3 は重合温度の影響 溶媒の影響a)

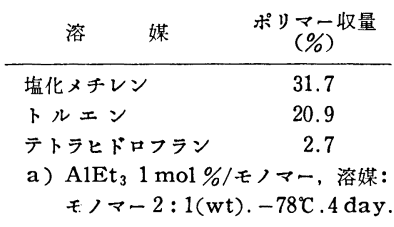

表 3 ClPA の重合におよぼす 温度の影響日)

\begin{tabular}{rr} 
温 $_{\left({ }^{2} \mathrm{C}\right)}$ & $\begin{array}{c}\text { ポリ } \\
(\%)\end{array}$ \\
\hline 0 & $<$ 收量 \\
-21 & $<0.1$ \\
-45 & 0.3 \\
-78 & 2.2 \\
-90 & 33.4 \\
-100 & 40.5 \\
\hline
\end{tabular}

a) $\mathrm{AlEt}_{3} 1 \mathrm{~mol} \% /$ モノマー. 塩化メ チレン:モノマー $2: 1(w t) .1$ day. をしらべた結果の一例で, $-45^{\circ} \mathrm{C}$ 以上の温度ではポリマーはほ とんど得られず, $-90^{\circ} \mathrm{C}$ 付近に収量の最大がある。 $-78^{\circ} \mathrm{C}$ およ び $-90^{\circ} \mathrm{C}$ に扣ける収量の時間变化を追ったのが図 2 で, これら の条件下では反応開始後数時間で実際上飽和収量に達している。

表 4 は開始剤としての一連のアルミニウム化合物の酸強度の影 響をみたもので，高いポリマー収率を得るためには適当な酸強度 をもった触媒種が必要で, $\mathrm{AlCl}_{3}$ や後に述べる $\mathrm{TiCl}_{3}$ 打よび $\mathrm{TiCl}_{4}$ のようなつよいルイス酸による重合ではポリマーはほとんど得ら れない。

有機アルミニウム化合物とチタン塩化物との複合開始剂による CIPA の重合を試みた。二, 三の結果を表示すると表 $5 〜 7$ にな る。

\begin{tabular}{|c|c|c|c|}
\hline \multicolumn{2}{|c|}{ 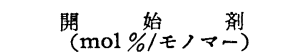 } & 時 $(\text { day })^{\text {間 }}$ & $\begin{array}{c}\text { ポリマー收量 } \\
(\%)\end{array}$ \\
\hline $\mathrm{AlEt}_{3}$ & 1.0 & 2 & 33.4 \\
\hline $\mathrm{AlEt}_{3}-\mathrm{AlEt}_{2} \mathrm{Cl}$ & $0.5-0.5$ & " & 37.9 \\
\hline $\mathrm{AlEt}_{2} \mathrm{Cl}$ & 1.0 & " & 10.5 \\
\hline $\mathrm{AlEt}_{3}-\mathrm{AlEtCl}_{2}$ & $0.5-0.5$ & " & 7.6 \\
\hline $\mathrm{AlEt}_{2} \mathrm{Cl}-\mathrm{AlEtCl}{ }_{2}$ & $"$ & " & 5.0 \\
\hline $\mathrm{AlCl}_{3}$ & 5.0 & 4 & 0.2 \\
\hline
\end{tabular}

表 4 ポリマー収量に扰よぼすアルミニウム化合物の 酸強度の影響到 
表 $5 \quad \mathrm{AlEt}_{3}-\mathrm{TiCl}_{4}$ 系開始剤による $\mathrm{ClPA}$ の重合 ${ }^{\mathrm{a}}$

\begin{tabular}{|c|c|c|c|c|}
\hline 重合方法b) & $\begin{array}{l}\mathrm{Ti} / \mathrm{Al} \\
\text { (モル此) }\end{array}$ & $\begin{array}{c}\text { 開始剤熟成時間 } \\
(\mathrm{min})\end{array}$ & $\begin{array}{l}\text { 重合時間 } \\
\text { (day) }\end{array}$ & $\begin{array}{c}\text { ポリマー収量 } \\
(\%)\end{array}$ \\
\hline \multirow{13}{*}{ I } & 4.0 & 15 & 4 & 1.2 \\
\hline & 1.0 & 1 & " & 1.7 \\
\hline & 0.25 & "I & $"$ & 2.3 \\
\hline & 4.0 & 30 & $"$ & 0.4 \\
\hline & 1.0 & "I & $"$ & 2.0 \\
\hline & 0.25 & " & $"$ & 3.6 \\
\hline & c) & 90 & $"$ & $<0.1$ \\
\hline & 8.0 & $"$ & "I & $<0.1$ \\
\hline & 4.0 & " & $"$ & 1.0 \\
\hline & 1.0 & $"$ & "I & 2.7 \\
\hline & 0.25 & $"$ & "I & 5.3 \\
\hline & 0.125 & $"$ & " & 7.0 \\
\hline & 0 & " & "I & 25.2 \\
\hline \multirow{6}{*}{ II } & c) & "I & 5 & 1.2 \\
\hline & 8.0 & " & "I & $<0.1$ \\
\hline & 4.0 & " & $" 1$ & 0.3 \\
\hline & 1.0 & " & " & 2.2 \\
\hline & 0.125 & $"$ & "I & 3.9 \\
\hline & 0 & $"$ & "I & 28.6 \\
\hline
\end{tabular}

a) $\mathrm{AlEt}_{3} 1 \mathrm{~mol} \% /$ モノマー. 塩化メチレン $2:$ モノマー $1(\mathrm{wt}) .-78^{\circ} \mathrm{C}$.

b) I : 溶煤で希釈した有機アルミニウムとチタン化命物とを試験管中で窒素気流 下に室温で混合熟成したのち、 $-78^{\circ} \mathrm{C}$ に冷却しながら泠モノマー溶液を加え る．II：モノマーとチタン化合物とを溶媒中で混合し，窒素枸流下室温に打い て，ときどき振りまぜながら熟成し， $-78^{\circ} \mathrm{C}$ に冷却して冷有機アルミニウム 溶液を添加して重合を開始させる。

c) $\mathrm{TiCl}_{4}$ 単独.

表 5 にしるしたよ5に開始剤とモノマーの仕込順序（重合方法 IおよびII）や熟成時間を変えてもポリマー収量には目立った変 化はない。ClPA はチタン塩化物によってはほとんど重合を起 こさず，有機アルミニウムに少量のチタン塩化物を添加した複 合系によっても重合はあまり進まない。また $\mathrm{AlEt}_{2} \mathrm{Cl}-\mathrm{TiCl}_{4}$ 系 では Ti/Al モル比のポリマー収量におよぼす効果もはっきり認

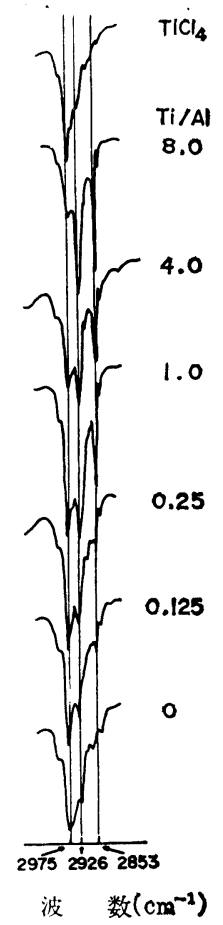

図 3 種々の $\mathrm{TiCl}_{4} / \mathrm{AlEt}_{3} モ ル$ 比で得たポリクロルェチル オキシメチレンの赤外吸収 の比較

重合条件 : $\mathrm{AlEt}_{3} 1 \mathrm{~mol} \% / € ノ マ ー$, 塩化メチレン $2: モ ノ マ ー 1(w t),-78^{\circ} \mathrm{C}$, 4 day.
も現われた。図 3 に $\mathrm{AlEt}_{3}-\mathrm{TiCl}_{4}$ 系複合開始剤による生成ポリマ 一の IR スペクトルを種々の Ti/Al 比について比較した。 Ti/Al モル比の増加とともに $2975 \mathrm{~cm}^{-1}$ の吸収は弱くなり, 逆に 2925 牤よび $2850 \mathrm{~cm}^{-1}$ の吸収は強くなる。このことは $\mathrm{AlEt}_{3}-\mathrm{TiCl}_{3}$ 系によるポリマーでもまったく同様に観測された。この現象のポ リマー構造との関連性については現在のところ明確ではない。

前にも触れたが $\mathrm{TiCl}_{4}$ や $\mathrm{TiCl}_{3}$ では実際上 $\mathrm{ClPA}$ の高重合体 は生成し難い。塩酸のよ5な強酸では線状重合体はまったく生成 せずもっぱら環状三量体である $2,4,6$-トリス ( $\beta$-クロルェチル) sートリオキサンが容易に生成する。また $\mathrm{BF}_{3} \mathrm{OEt}_{2}$ を開始剤に用 いると，たとえばモノマー 1 部に対し 2 部の塩化メチレン中，開 始剤濃度 $1 \mathrm{~mol} \% / モ ノ マ ー,-78^{\circ} \mathrm{C}$ において 3 日間の重合で, $11.8 \%$ の収率でゴム状弾性体が得られる。これを溶かす溶媒が みあたらなかったので分子量を測定してはいないが，有機アルミ ニウム系開始剂によって生成するものにくらべて低い分子量をも った非晶性ポリマーであると考える。

表 8 は比較のために行なった $\mathrm{DCPA}$ の $\mathrm{AlEt}_{3}-\mathrm{TiCl}_{4}$ 系複合開 始剂による重合の結果である。 この場合は明らかにポリマー収 量の最大が $\mathrm{Ti} / \mathrm{Al}$ モル比 $=1$ の ところに存在する。そして CIPA の場合とは異なって，モノマー と開始剂の仕込順序や $\mathrm{Ti} / \mathrm{Al}$ 配 合比によるポリマーの IR スペ クル上の変化は認められなかっ た。ClPA と DCPA とのこれ 表 $8 \mathrm{AlEt}_{3}-\mathrm{TiCl}_{4}$ による

\begin{tabular}{cc}
$\begin{array}{c}\text { DCPA } \\
\text { Ti/A1 } \\
\text { (モル比) }\end{array}$ & $\begin{array}{c}\text { の重合a) } \\
\text { ポリマー收量 } \\
(\%)\end{array}$ \\
\hline b) & 2.0 \\
8.0 & 32.2 \\
4.0 & 44.0 \\
1.0 & 53.3 \\
0.25 & 21.5 \\
0.125 & 24.8 \\
0 & 24.1
\end{tabular}

a) $\mathrm{AlEt}_{3} 1 \mathrm{~mol} \% /$ モノマー. モノ マー1: 塩化メチレン $2(w t)$. $-78^{\circ} \mathrm{C}$. 4 day.

b) $\mathrm{TiCl}_{4}$ 単独. $1 \mathrm{~mol} \% /$ モ ママー. らの挙動のちがいについては今後の研究にまつところが多いが興 味あることである。

\section{$3 \cdot 2$ ClPA と CPA との共重合}

$\mathrm{AlEt}_{3}$ を開始剤として塩化メチレン中 $-78^{\circ} \mathrm{C}$ に拈いて ClPA と CPA とを共重合させ，生成ポリマーを DMF 不溶分と可溶分 とに溶出分別し，それぞれについて元素分析結果から組成を求め た結果を表 9 に例示する。

表 $9 \mathrm{ClPA}$ と CPA との共重合生成物の組成 ${ }^{\mathrm{a}}$

\begin{tabular}{|c|c|c|c|c|c|c|}
\hline \multirow{3}{*}{ 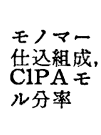 } & \multirow{3}{*}{$\begin{array}{l}\text { 重畣率 } \\
\end{array}$} & \multicolumn{4}{|c|}{ 共重合生成物中の C1PA モル分率 } & \multirow{3}{*}{$\begin{array}{l}\text { DMF 可 } \\
\text { 㳵分の分 } \\
\text { b) }\end{array}$} \\
\hline & & \multicolumn{2}{|c|}{ DMF 不溶分 } & \multicolumn{2}{|c|}{ DMF 可溶分 } & \\
\hline & & $\begin{array}{l}\text { C 含量 } \\
\text { 量 }\end{array}$ & $\begin{array}{l}\mathrm{N} \text { 含量 } \\
\text { 夏 }\end{array}$ & $\begin{array}{l}\text { C 含量 } \\
\text { b }\end{array}$ & $\begin{array}{l}\mathrm{N} \\
\text { か 含量 }\end{array}$ & \\
\hline 0. & 54.2 & 0.79 & 0.8 & 0.78 & 0.77 & 4500 \\
\hline 0. & 52.9 & 0.49 & 0.51 & 0.53 & 0.49 & - \\
\hline 0.2 & 68.6 & 0.20 & 0.17 & 0.18 & 0.21 & 4700 \\
\hline
\end{tabular}

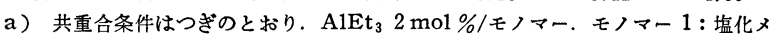
チレン $2(\mathrm{wt}) .-78^{\circ} \mathrm{C} .2$ day

b) VPO 法. DMF 中 $37^{\circ} \mathrm{C}$ て測定

表 $7 \quad \mathrm{AlEt}_{2} \mathrm{Cl}-\mathrm{TiCl}_{4}$ 系開始剤 による ClPA の重合a)

\begin{tabular}{cc}
$\begin{array}{c}\mathrm{Ti} / \mathrm{A} 1 \\
\text { (モル比) }\end{array}$ & $\begin{array}{c}\text { ポリマー収量 } \\
(\%)\end{array}$ \\
\hline $\mathrm{b})$ & $<0.1$ \\
4.0 & $<0.1$ \\
1.0 & 5.5 \\
0.25 & 4.9 \\
0.125 & 4.8
\end{tabular}

a) $\mathrm{AlEt}_{2} \mathrm{Cl} 1 \mathrm{~mol} \% /$ モノマー. 塩 化メチレン 2:モノマー1(wt). 開始剂就成：窒素中室温 $90 \mathrm{~min}$. 重合時間: 4 day

b) $\mathrm{TiCl}_{4}$ 単独. $1 \mathrm{~mol} \% /$ モノマー.
比較的高い重合率で得た試料であるがいずれも，モノマー仕込 組成と重合体組成，DMF 不溶分と可溶分との組成，括よび炭素 含量から求めた值と窒素含量から求めた値とはたがいにほぼ一致 している。つぎに同じ組成になるように両ホモポリマーを混合し たものと溶解性を比較してみると表 10 のと和りになる。

共重合生成物の方が明らかに溶解性が大きく，かつ共重合によ って両ホモポリマーのいずれよりも溶解性に富むポリマーを得る ことができることを示している。表 9 扣よび表 10 に示した事実 からここに得られたポリマーは共重合体であるといえる。図4 に 
表 10 DMF に対する共重合生成物とホモポリマー混合物 との溶解性の比較

\begin{tabular}{|c|c|c|c|}
\hline 試 & \multirow{2}{*}{$\begin{array}{l}\text { 組成, C1PA } \\
\text { モ分率 }\end{array}$} & \multicolumn{2}{|c|}{ DMFによる溶出分別結果b) } \\
\hline 料 ${ }^{\mathrm{a}}$ & & $\begin{array}{c}\underset{(\%)}{\text { DMF 不溶分 }} \\
(\%)\end{array}$ & $\begin{array}{c}\mathrm{DMF} \text { 可溶分 } \\
(\%)\end{array}$ \\
\hline \multirow{2}{*}{$\begin{array}{l}\mathrm{C} 1 \mathrm{PA} \text { ホモポリマー } \\
\text { 共重合生成物 }\end{array}$} & 1.0 & 94.6 & 5.4 \\
\hline & 0.8 & 64.0 & 36.0 \\
\hline 混 合 物 & $"$ & $84.6(82.1)$ & $15.4(17.9)$ \\
\hline 共重合生成物 & 0.5 & 51.9 & 48.1 \\
\hline 混 合 物 & $" \prime$ & $64.4(63.3)$ & $35.6(36.7)$ \\
\hline 共重合生成物 & 0.2 & 14.2 & 85.8 \\
\hline 混 合 物 & $" \prime$ & $48.7(44.5)$ & $51.3(55.5)$ \\
\hline CPA ホモポリマー & 0 & 32.0 & 68.0 \\
\hline
\end{tabular}

a) 共重合生成物各試料は表 9 のそれぞれの試料と同一のものである.

b） カッコ内の数值は両単独ポリマーの溶出分別結果から推算したもの.

表 11 ClPA-CPA 共重合に抢ける共重合体の組成と 溶解性の経時变化 ${ }^{\mathrm{a}}$

\begin{tabular}{|c|c|c|c|c|}
\hline \multirow{2}{*}{ 時 $(\mathrm{hr})^{\text {間 }}$} & \multirow{2}{*}{$\begin{array}{c}\text { 重念率 } \\
(\%)\end{array}$} & \multirow{2}{*}{$\begin{array}{l}\text { 共重倉体組成, } \\
\text { 㮦 }\end{array}$} & \multicolumn{2}{|c|}{ DMFによる溶出分別結果 } \\
\hline & & & $\begin{array}{c}\text { DMF 不溶分 } \\
(\%)\end{array}$ & $\begin{array}{c}\text { DMF 可溶分 } \\
(\%)\end{array}$ \\
\hline 0.25 & 4.5 & 0.51 & - & - \\
\hline 0.5 & 13.3 & - & 56.0 & 44.0 \\
\hline 1.0 & 16.2 & 0.47 & 51.4 & 48.6 \\
\hline 2.0 & 28.5 & 0.52 & 48.3 & 51.7 \\
\hline 4.0 & 39.7 & 0.52 & 49.9 & 50.1 \\
\hline 18.0 & 58.9 & 0.47 & 45.5 & 54.5 \\
\hline 48.0 & 52.9 & 0.50 & 51.9 & 48.1 \\
\hline
\end{tabular}

a) モノマー仕込組成 $1: 1(\mathrm{~mol})$. モノマー 1:塩化メチレン $2(\mathrm{wt}) . \mathrm{AlEt}_{3}$ $2 \mathrm{~mol} \% /$ モノマー. $-78^{\circ} \mathrm{C}$

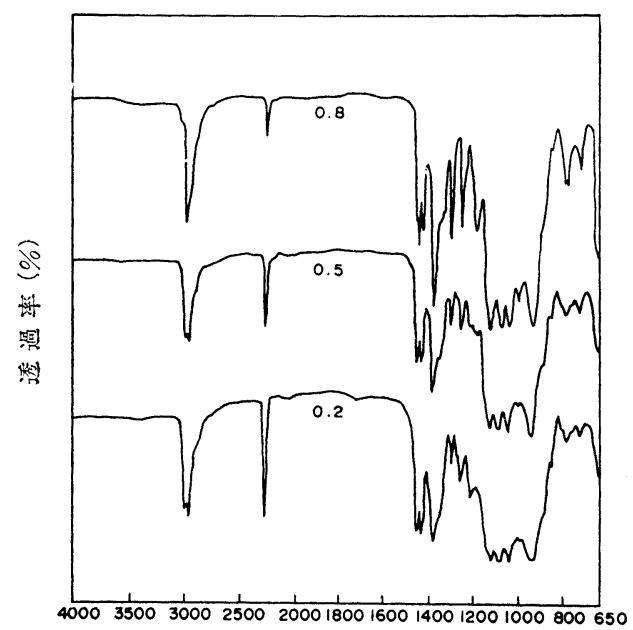

$$
\text { 波 数 }\left(\mathrm{cm}^{-1}\right)
$$

図 4 ClPA-CPA共重合体の赤外吸収スペクトル (フィルム)

四中の数值は C1PA のモル分率であらわした組成を示す

これら共重合体からつくったフィルムについて測定した IR スペ クトルを掲げた。

$\mathrm{ClPA}$ と $\mathrm{CPA}$ とを等モル混合して, $\mathrm{AlEt}_{3}$ を開始剤として塩 化メチレン中 $-78^{\circ} \mathrm{C}$ に打いて共重合させる場合について, 重合 経過に伴なら共重合体の組成抽よび DMF 溶解性の変化を追った 結果が表 11 である。重合の初期から後期まで生成共重合体の組

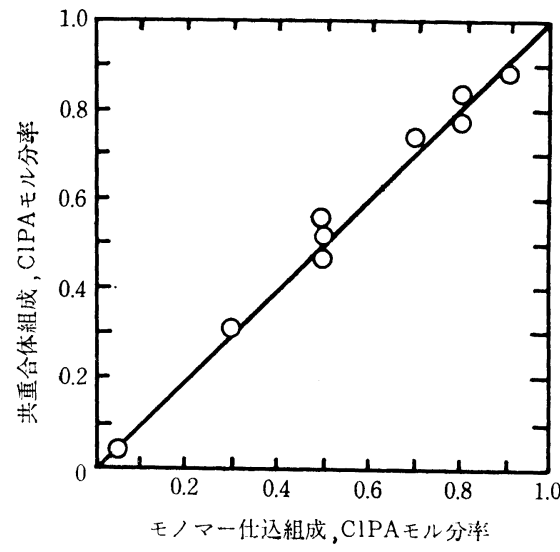

図 $5 \mathrm{ClPA}$ と CPA との共重合に拈けるモノマー 仕込組成と初期共重合体組成との関係

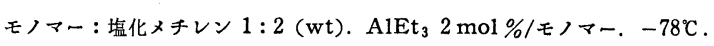

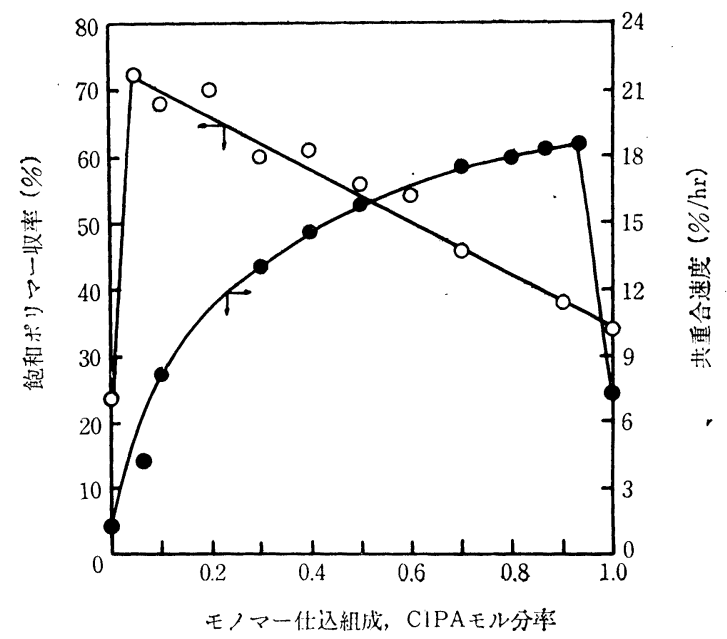

図 $6 \mathrm{ClPA}$ と CPA との共重合に拈ける飽和ポリマー 収率括よび共重合速度のモノマー仕込組成依存性

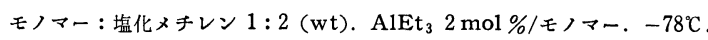
○: 重合時間 2 day 飞捄いて求めた飽和收率, ○：同 $1.5 \mathrm{hr}$ と扰ける共 重合速度 $(\% / \mathrm{hr})$

成も溶解性も変わらない。このことはモノマー仕込組成を変えて も同様で，モノマー仕込組成と初期共重合体組成との関係をみる と図 5 に示すよ5にほぼ対角線上にのり, この共重合がランダム なアゼオトロープ共重合 $\left(r_{1}=1, r_{2}=1\right)$ であることがわかる。

種々のモノマー仕込組成において 2 日間共重合させて得られる 飽和収率および重合時間 $1.5 \mathrm{hr}$ に括ける単位時間あたりのポリ マー収率であらわした重合速度を図示すると図6のよ5になり， 共モノマーの少量添加によって最大の共重合速度または飽和収率 が達せられるという興味ある事赛がみいだされた。

(1969 年 10 月 14 日, 化学関係学協会連合秋季大会 (名古屋) 拈上び 1970 年 4 月 3 日, 日本化学会第 23 年会 (東京) 講演) 